\title{
Pensonomonoor
}

2017, vol. 78, 96-110

http://dx.doi.org/10.12657/denbio.078.010

\author{
Arailym Kopabayeva, Kuralay Mazarzhanova, Nesibe Köse, \\ Ünal Akkemik*
}

\section{Tree-ring chronologies of Pinus sylvestris from Burabai Region (Kazakhstan) and their response to climate change}

Received: 21 February 2017; Accepted: 23 June 2017

\begin{abstract}
Pinus sylvestris L. (Scots pine) is the main forest tree species in Burabai National Park. Trees here grow under continental climate conditions. There are no dendroclimatological studies based on Scots pine of this region. The purpose of this study was to find the relationships between tree-ring widths and climate. For this purpose, a total of 176 cores from 100 Scots pine trees were collected. After measuring tree-ring widths, standard chronology building methods were used, and three site chronologies were constructed. Correlation coefficients between tree-ring widths with temperature and precipitation were calculated. Precipitation from October of the previous year to July of current year had a positive influence on tree-ring widths and August-September precipitation have the opposite effect. Temperature in the winter had positive effect for tree-ring growth but significantly negative during summer. Effects of climate changes on tree-ring widths were observed. The variation and sensitivity of tree-ring widths increased after 1940s. An increasing trend in precipitation, temperature, and tree-ring widths were clearly observed. In conclusion, tree-rings of Scots pine in Burabai are highly sensitive to growing site conditions and are affected by climate changes.
\end{abstract}

Keywords: Dendroclimatology, Kazakhstan, Burabai, climate change

Addresses: A Kopabayeva, K Mazarzhanova, S. Seyfullin Agroteknik University, Agromonia Faculty, Forest Resourches and Forestry Department, Astana/Kazakhstan N Köse, Ü Akkemik*, Istanbul University, Forestry Faculty, Forest Botany Department, Bahçeköy, Istanbul/Turkey, e-mail: uakkemik@istanbul.edu.tr

*Corresponding author

\section{Introduction}

Dendroclimatology is one of the most important tools to understand the nature of climate and its changes. Hughes (2002) stated that the climate signal on tree rings can be seen at spatial scales ranging from a few hectares to a hemisphere, and at temporal scales from a few hours to centuries in atmospheric circulations. In recent years, hemisphere-wide tree ring-based climate data are getting produced. George and Ault (2014) stated that summer precipitation is the most important positive factor affecting tree-ring widths in the mid-latitudes, while summer temperature has strong negative influence. Wilson et al. (2016) 
performed a large scale May to August temperature reconstruction and long term changes for the Northern Hemisphere showing temperature has an increasing trend in recent centuries. Cook et al. (2015) described the effects of Medieval Climate Anomaly and Little Ice Age based on tree-ring reconstructions by studying megadroughts in Europe and the Old World.

In different regions of the world, dendroclimatological studies revealed valuable local climate history information. D'Arrigo et al. (2000) performed annual temperature reconstruction in Mongolia and stated that there is an increasing trend in temperature after the 1800s. Numerous dendroclimatological studies were performed in northern Europe (e.g. Esper et al., 2007; Kausrud et al., 2010; Corona et al., 2010; Tegel et al., 2010; Büntgen et al., 2011; Büntgen et al., 2016; Gogou et al., 2016; Luterbacher et al., 2016; Xoplaki et al., 2016; Holmgren et al., 2016), in the eastern Mediterranean basin (e.g. Touchan et al., 2005; Touchan et al., 2007; Akkemik \& Aras, 2005; Akkemik et al., 2005; Akkemik et al., 2008; Köse et al., 2011; Köse et al., 2013), in central Asia (e.g. Yuan \& Li, 1999; Yuan et al., 2001; Esper et al., 2002; Yuan et al., 2003; Chen et al., 2009; Chen et al., 2010), in the southern Urals (Agafonov \& Kukarskikh, 2008) and in Siberia (Rigling et al., 2001; Babushkina et al., 2015; Shah et al., 2015).

However, Kazakhstan has been the subject of very few dendroclimatological studies. Pugachev (1986) explained that the growth of Pinus sylvestris in the steppe forests of Turgai (Kustanai region, Kazakhstan). Chen et al. (2010) reconstructed tree-ring density-based summer temperature for the time span of 1600-2002. Dyakonov and Retejum (2015) stated that the 1920s reflected major tree-ring anomalies including a huge famine event. This event caused 7-8 million deaths in Ukraine, Russia, Kazakhstan and China. The recent dendroclimatology study in Kazakhstan was on tree ring-analysis of Pinus sylvestris from Shalday Pine Forest in the northeastern Kazakhstan (Mapitov \& Zhumadina, 2016). This study reveals that May precipitation has a significantly positive effect on tree-ring growth, while May temperature has significantly negative influence.

Burabai Region is one of the most important forest areas of Kazakhstan. This region has a wide Pinus sylvestris forest, which is pure and mixing with Betula alba in some parts. Because of the lack of dendroclimatological studies in Burabai Region of Kazakhstan and having old Pinus sylvestris forests, the purpose of the present study was (1) to build tree ring chronologies of Pinus sylvestris for this region, (2) to determine the relationships between tree-ring widths and climatic parameters (mean monthly temperatures and total monthly precipitation), and (3) to find the effect of climate change on tree-ring widths. According to the Synthesis Report 2014 of IPCC published in 2015, temperature has been increasing in most parts of the world. Precipitation increase will not be uniform and will be more in higher latitudes when temperature will be increasing uniformly. One of the most important changes in climate is the increase in the frequency of extreme events after 1950 (IPCC, 2015). We expect that dendroclimatological studies will provide useful information on climate change in Burabai Region, where dendroclimatological results are lacking and instrumental records scarce.

\section{Study area}

Burabai Region, which is one of the National Natural Parks of Kazakhstan, is located in north-central Kazakhstan, and covers an area of 129,000 ha including forests, lakes, and villages (Fig. 1). Pinus sylvestris is the main tree species in this forest with an area of $65 \% .31 \%$ of the area is covered by Betula pendula L., and the remaining 3\% with Populus tremula L. and $1 \%$ with shrubs (Fig. 2). These three species grow naturally in the forests we studied, while it is possible to see Pinus sylvestris plantations around cities. It is located on the territory of Akmola, in the most elevated part of the northern margin of Kazakh Hummocks. In the northern part, it reaches its maximum elevation (Mount Kokshetau, 947.6 m a.s.1.). Further to the south, there is Mount Burabay (690.0 $\mathrm{m}$ a.s.l. and Mount Zheke-Batir (826.2 m a.s.l.) In the southern part of the mountain chain, elevation starts to decrease to $400-500 \mathrm{~m}$ a.s.l. There are many lakes in Burabai Region called Borovoye, Shchuchye, Chebachye, Maybalyk and Katarkol. The climate is sharply continental, with hot summers and hard dry winters. The annual precipitation is $250-295 \mathrm{~mm}$ in the lowland and up to $400 \mathrm{~mm}$ in the hilly part (Fig. $3)$. The stable period with average daily temperatures higher than $5^{\circ} \mathrm{C}$ lasts from late April to early October, and the snow cover is established from October to April. The average temperature in June is $18-20^{\circ} \mathrm{C}$, its average maximum ranges $38-40^{\circ} \mathrm{C}$. The coldest month is January and average temperature in this month is -17 to $-18^{\circ} \mathrm{C}$ (the absolute maximum $-30^{\circ} \mathrm{C}$ ) (Petrova \& Sultangazina, 2015).

\section{Material and Methods}

\section{Chronology development}

Tree-ring samples were taken from three different sites in Burabai Region (Fig. 1; Table 1). A total of 176 cores from 100 natural trees of Pinus sylvestris (Fig. 4) were extracted using increment borers. All samples were sent to the Laboratory of Tree-Ring Research at Forestry Faculty (Istanbul University) 


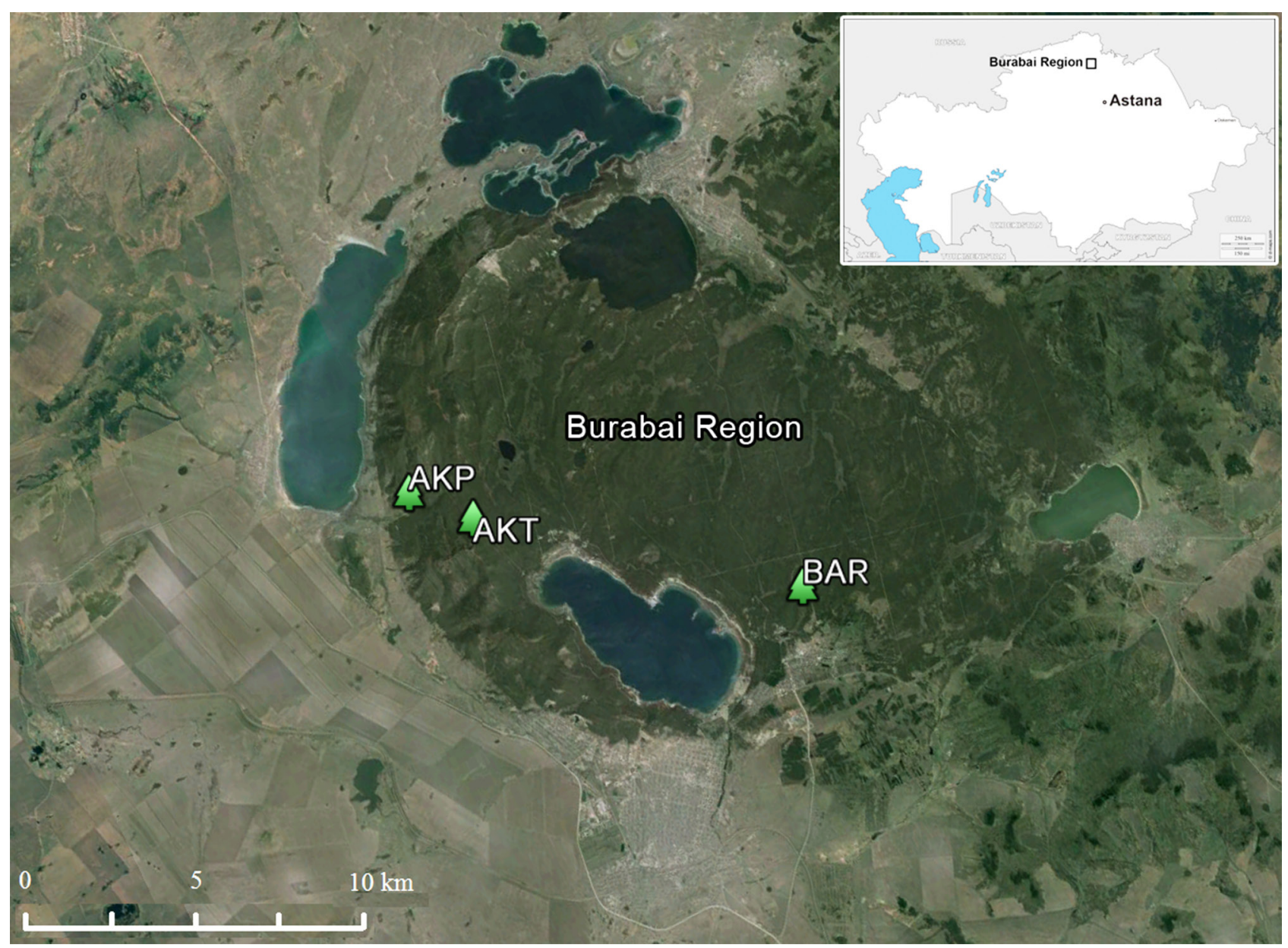

Fig. 1. The study region where is Burabai National Park and sampling areas

for standard dendrochronology analysis. The cores were mounted on carriers and sanded to see treering borders clearly. Before measuring, each core was sectioned 10-year segments to see possible problems visually and then tree-ring measurements were performed by using LINTAB-TSAPWin Measuring System (Rinntech, Germany).

COFECHA Program (Holmes, 1983) was used for each site separately to check for potential problems and the quality of the measurements. ARSTAN Program (Cook, 1985) was run to build site chronologies. First, each ring-width series was detrended by fitting a negative exponential regression function to remove non-climatic trends such as age related trends (Cook, 1985). Then, the each detrended series were combined into site chronologies using biweight robust mean (Cook et al., 1990). We used residual chronologies for further analysis, removing autocorrelation from individual detrended series using autoregressive models. The correlation coefficients and coefficient of agreement (Gleichläufigkeit -GLK) value (Eckstein \& Bauch, 1969) were calculated to show similarities between three site chronologies. Significant and very high correlations were encouraged us to build a regional residual chronology using all samples from three sites.

The following descriptive statistics for the chronologies, such as correlation coefficients, signal-to-noise

Table 1. Site information where was collected samples

\begin{tabular}{|c|c|c|c|c|c|c|c|}
\hline Site code & Site name & Elevation (m) & Slope (\%) & Aspect & $\begin{array}{c}\text { Latitude (N) } \\
\text { Longitude (E) }\end{array}$ & Soil depth & Core/Tree number \\
\hline AKP & Akylbai Plain & $360-440$ & 15 & Flat plain site & $\begin{array}{l}\text { N } 53^{\circ} 02^{\prime} 13.5 \\
\text { E } 70^{\circ} 08^{\prime} 12.4\end{array}$ & Deep & $57 / 34$ \\
\hline AKT & Akylbai Top Mountain & $750-850$ & 35 & South-Southwest & $\begin{array}{l}\text { N } 53^{\circ} 01^{\prime} 21.6 \\
\text { E } 70^{\circ} 09^{\prime} 30.8\end{array}$ & Shallow & $32 / 17$ \\
\hline \multirow[t]{2}{*}{ BAR } & Barmashino & $460-470$ & 15 & Flat plain site & $\begin{array}{l}\text { N } 52^{\circ} 58^{\prime} 9.3 \\
\text { E } 70^{\circ} 16^{\prime} 36.7 \\
\end{array}$ & Deep & $87 / 49$ \\
\hline & & & & & & Total & $176 / 100$ \\
\hline
\end{tabular}




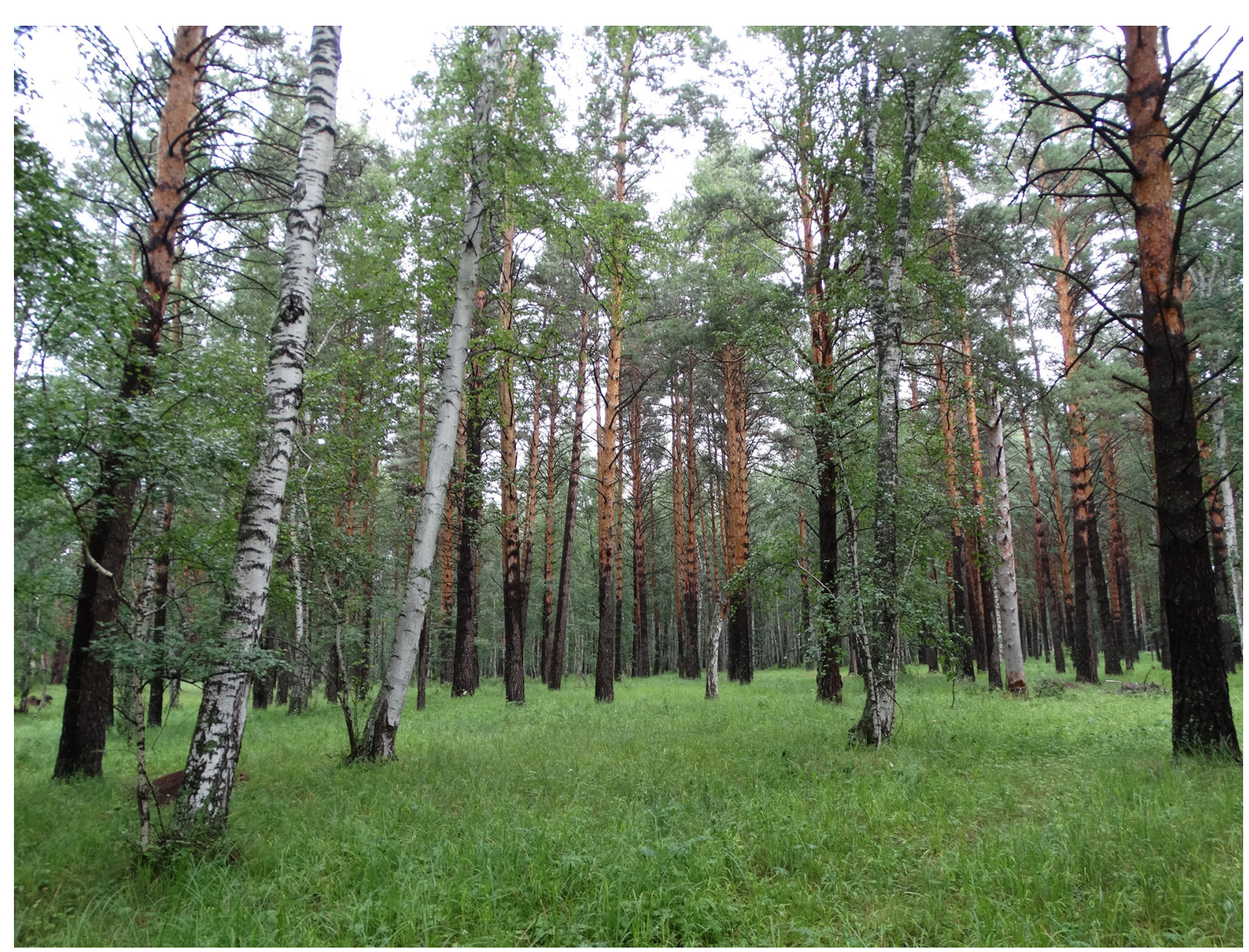

Fig. 2. General view of a mixed forest in the Burabai Region composed of Pinus sylvestris and Betula pendula

ratio (SNR), mean sensitivity, and variance of the first eigenvector, were calculated for common intervals to show the quality and characteristics of the chronologies. SNR explains strength of the common signals among trees in the investigated population (Cook et al., 1990). Mean sensitivity (Fritts, 1976) was calculated to measure the sensitivity of the series:

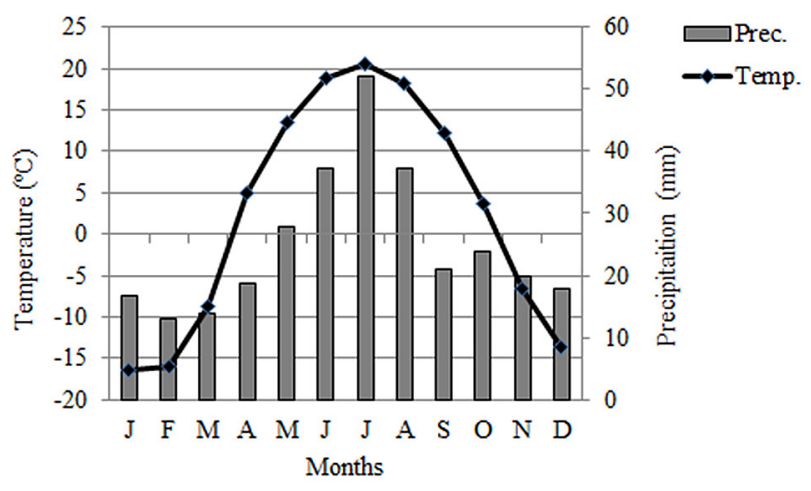

Fig. 3. Climate diagram of Burabai Region. Annual precipitation is about $300 \mathrm{~mm}$ and the much rainy season is June to August

$$
\begin{gathered}
\text { Annual sensitivity } S_{i}=2\left(X_{i}-X_{i-1}\right) /\left(X_{i}+X_{i-1}\right) \\
\text { Mean sensitivity (MS) }=\sum\left|S_{i}\right| /(n-1)
\end{gathered}
$$

where $X_{i}$ and $X_{i-1}$ are tree-ring widths in the years of $i$ and $i-1 . n$ is the number of tree rings. Fritts (1976) stated that the reason of yearly changes on tree-ring width is climate and in extreme changes sensitivity ratio increases. Bunn et al. (2013) stated that mean sensitivity was conceived as a statistic that would indicate if a series was useful for crossdating or responsive to climate. In this study, we calculate the magnitude of year-by-year sensitivity of tree-ring series to find if there is any change in sensitivity.

We used the threshold that the expressed population signal (EPS) $>0.85$ (Wigley et al., 1984), to decide minimum sample depth of each site chronology.

\section{Radial growth - climate relationship}

Monthly climate data was obtained from KNMI Climate Explorer for the period of 1950 to 2014, which is the time span of available meteorological records in the region for latitudes and longitudes $50-54^{\circ} \mathrm{N}$ 

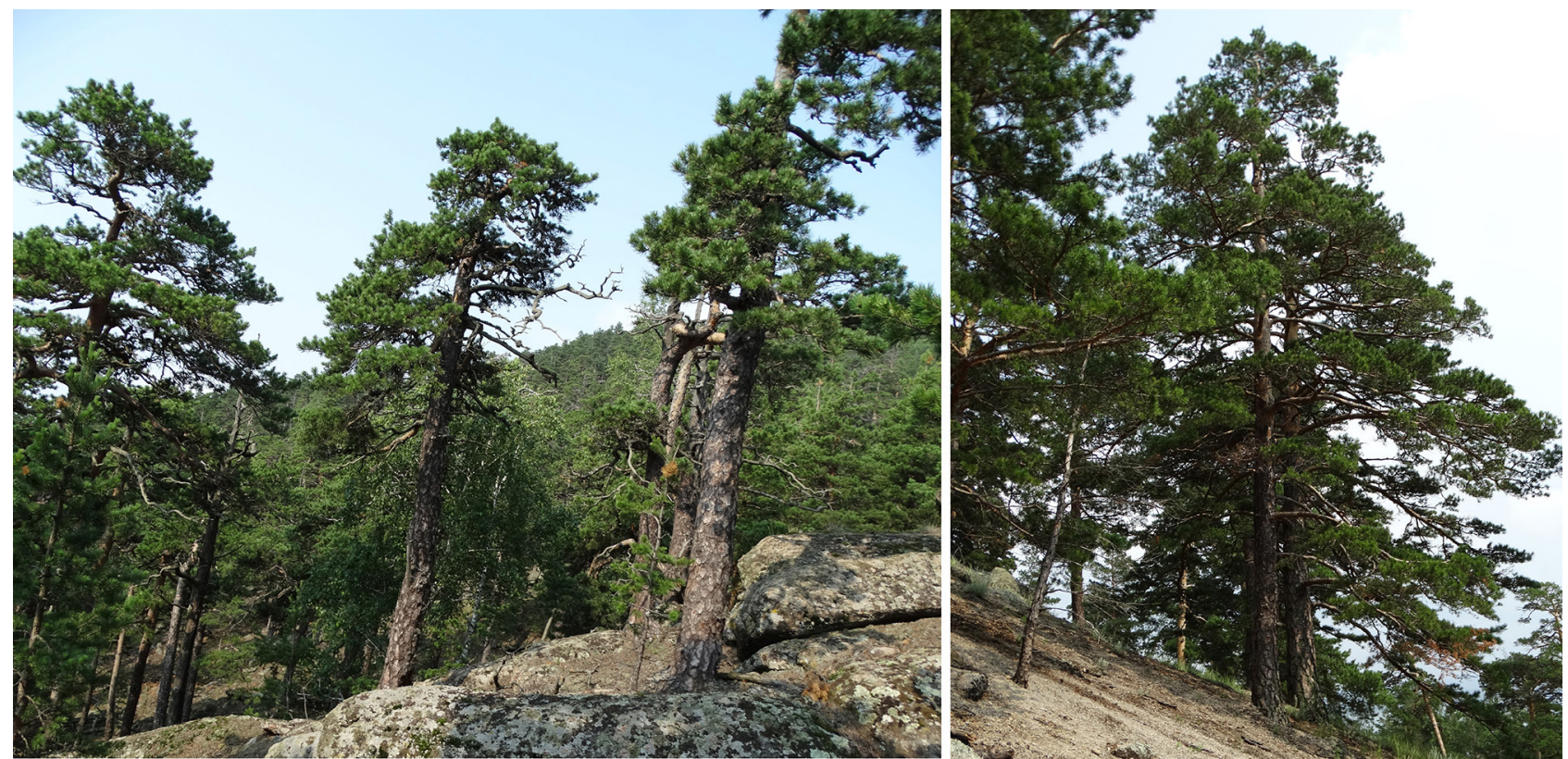

Fig. 4. Old Pinus sylvestris trees sampled in AKT site (left) and Pinus sylvestris trees in BAR Site (right)

$\times \quad 69-72^{\circ} \mathrm{E}$, respectively. Correlation coefficients were calculated between tree-ring chronologies and monthly mean temperature and total precipitation from October of the previous year to September of current year (Fritts, 1976) to find out the effect of climate on radial growth of Scotch pine in the region. We also ran the bootstrap correlation to evaluate the influence of climate variation. DENDROCLIM2002 Program (Biondi \& Waikul, 2004) used the bootstrap correlation and response function methods were preferred to calculate correlation coefficients between tree-ring chronologies and monthly mean temperature and total precipitation from October of the previous year to September of current year.

The most important climatic factors effecting Scots pine radial growth were also compared visually to the regional chronology during the instrumental period. For finding extreme years/periods 1-standard deviation (SD) of average of the mean chronology were calculated, and the years over 1-sd were considered as wet years, and those lower 1-sd as dry years.

\section{Results and Discussion}

\section{Site chronologies}

Three site chronologies were built for Burabai Region (Fig. 5). COFECHA results of samples obtained from three sites showed missing rings in certain years, while almost no double ring was found (Table 2). Rigling et al. (2001) stated that trees younger than 100 years in Siberia tend to produce IADF. We rarely observed intra-annual density fluctuation (IADF) caused by double ring formation in the younger parts of the trees growing in only low plain site, BAR. On the contrary, the numbers of determined missing rings are higher in AKP (35) and AKT (34) than that in BAR (5). The BAR site is located on the bottomland and on deep soil (Fig. 2). Because of this, tree-ring widths are wider in general and the number of missing rings is very low. On the contrary, the AKT site is on the top of the mountain and shallow soil, and also composed of older trees (Fig. 4). AKP site, which is located in lower land, is similar in number of missing rings to AKT site. For that reason the number of missing rings are too many in these two sites (Table 2).

Limited number of tree-ring chronologies of Pinus sylvestris was available for Kazakhstan (Mapitov \& Zhumadina, 2016). With this study, we contribute to a tree-ring network of Kazakhstan with three sensitive tree-ring chronologies of the species. The longest chronology (AKT) covers the years of 1772-2014,

Table 2. The number of trees having missing rings in the sites and the region

\begin{tabular}{ccccc}
\hline Years & AKP & AKT & BAR & The region \\
\hline 1795 & - & 1 & - & 1 \\
1953 & - & 3 & 3 & 6 \\
1965 & 1 & 1 & - & 2 \\
1967 & 1 & 2 & 1 & 4 \\
1977 & 7 & 2 & - & 9 \\
1984 & 3 & - & - & 3 \\
1987 & 5 & - & - & 5 \\
1990 & 5 & 6 & - & 11 \\
1991 & 4 & 17 & - & 21 \\
1998 & 3 & 1 & - & 4 \\
2004 & 6 & 1 & 1 & 8 \\
\hline Total & 35 & 34 & 5 & 74 \\
\hline
\end{tabular}



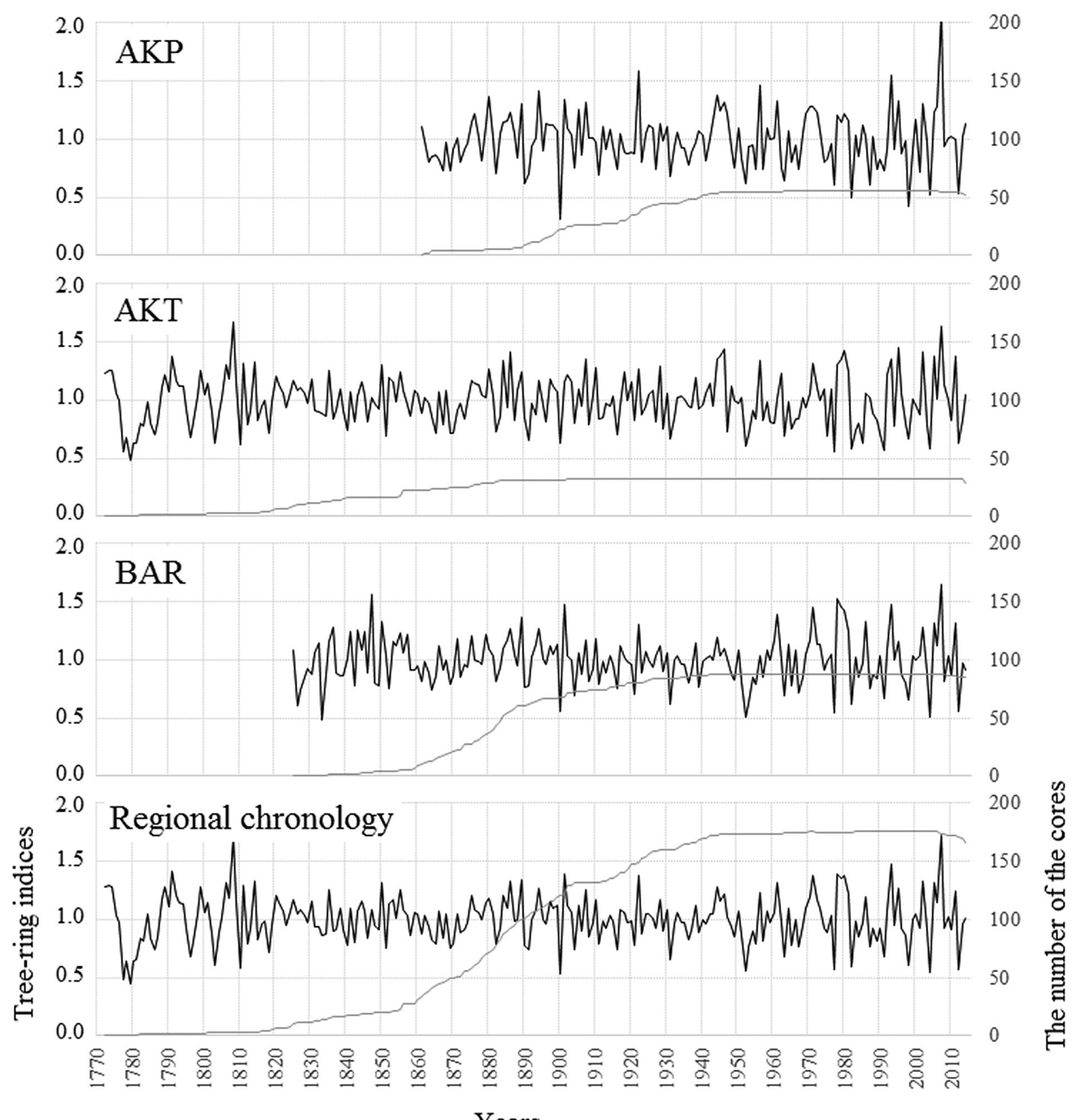

Years

Fig. 5. Residual versions of the three site chronologies and the regional chronology produced from these three site chronologies, and core depths

Table 3. Chronology statistics for residual version from ARSTAN Program

\begin{tabular}{lccc}
\hline & AKP & AKT & BAR \\
\hline Chronology time span & $1861-2014$ & $1772-2014$ & $1825-2014$ \\
Mean & $(34$ trees 57 radii $)$ & $(17$ trees 32 radii) & $(49$ trees 87 radii) \\
Mean sensitivity (MS) & 0.99 & 0.99 & 0.98 \\
Common interval & 0.27 & 0.23 & 0.24 \\
Correlations among all radii & $1928-2012(26$ trees 43 radii) & $1884-2013(17$ trees 31 radii) & $1904-2014$ (39 trees 71 radii) \\
Correlations between trees & 0.50 & 0.47 & 0.50 \\
Correlations within trees & 0.49 & 0.46 & 0.80 \\
Correlations radii vs mean & 0.70 & 0.65 & 0.71 \\
Signal-to-noise ratio (SNR) & 0.71 & 0.69 & 0.71 \\
Agreement with population chronology & 25.34 & 14.46 & 39.07 \\
Variance in first eigenvector (\%) (1EV) & 0.96 & 0.94 & 0.98 \\
\hline
\end{tabular}

All correlations are statistically significant $(\mathrm{p} \leq 0.001)$. 
Table 4. Correlation coefficients and Gleichlaufigkeit values among the site chronologies and their regional chronology

\begin{tabular}{|c|c|c|c|c|c|}
\hline & & \multicolumn{4}{|c|}{ Gleichlaufigkeit values (\%) } \\
\hline & & AKP & AKT & BAR & Regional chro. \\
\hline \multirow{4}{*}{ 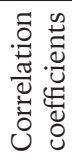 } & AKP & 1 & 69 & 78 & 85 \\
\hline & AKT & 0.69 & 1 & 67 & 77 \\
\hline & BAR & 0.79 & 0.66 & 1 & 79 \\
\hline & Regional Chro & 0.89 & 0.91 & 0.87 & 1 \\
\hline
\end{tabular}

All values are statistically significant $(\mathrm{p} \leq 0.001)$.

and the shortest one (AKP) 1861-2014. The BAR chronology time span is from 1825 to 2014.

Chronology statistics obtained from Arstan program were given in Table 3. All correlations between trees, within trees and their mean are significant. Both signal-to-noise ratio and the variance in the first eigenvector are rather high for all chronologies (Table 3). These higher values indicate that trees at each site share a similar signal. This high similarity is may reflect similar environmental factors, such as climatic variations. The mean sensitivity of the residual site chronologies are calculated as 0.23 for AKT site, 0.24 for BAR site, and 0.27 for AKP site. Scots pine trees have a very wide distribution area and therefor produce different sensitivity values. Rigling et al. (2001) stated that the sensitivity of the treering chronologies ranges $0.18-0.33$ in Swiss stands, $0.29-0.52$ in Russian stands on shallow soils on solid rocks and $0.17-0.22$ in sand dunes, and 0.21-0.25 in south-central Siberia (Babushkina al., 2015). It is $0.22-0.23$ in the west Black Sea region of Turkey (Akkemik et al., 2008). The sensitivity of the site chronologies in the study sites is at a medium level.

Results for EPS $>0.85$ revealed 6 trees (18872014) in AKP site, 7 trees (1824-2014) in AKT site, and 6 trees (1858-2014) in BAR site. Thus the interval, 1887-2014 (EPS > 0.85) is common for all three sites and may be used in further analyses.

We found very high and statistically significant $(\mathrm{p}<0.001)$ correlation coefficients and Gleichlaufigkeit values among the site chronologies (Table 4), which show that the trees share common climate signal in Burabai Region. This result is not surprising because of the geographical proximity of these sites. Therefore, we also built a regional chronology (Fig. 5) using all measurement series for dendroclimatological analysis.

\section{Tree-ring width and climate relationships}

Correlation coefficients between pre-whitened tree-ring indices for each site and also regional chronology, and gridded monthly mean temperatures and total monthly precipitation for October of the previous year to September of current year were calculated (Fig. 6).

Monthly mean temperature is generally positively correlated with tree-ring growth from October of the previous year to April of current year, while it is significant in November of the previous year for all sites. Similarly, the effect of precipitation is positive and generally significant in this month (Fig. 6). Trees experience very cold winters in central Asia and first frost occurs in November (Babushkina et al., 2015; Shah et al., 2015). Both higher temperatures and higher snow coverage in November can reduce frost effect and lead larger ring formation in Burabai Region. Babushkina et al. (2015) found similar positive effect of precipitation in this month and emphasized significant protective role of snow coverage on root system against first frosts in central Asia.

Quite the reverse, temperatures from May to August have generally a negative influence on tree-ring widths in all sites, but this effect was significant only for the trees from the AKP site for the period of May to July (Fig. 6). Mapitov and Zhumadina (2016) found that May temperature is one of the most limiting factors for the trees in Shalday pine forest in northeast Kazakhstan. Our study showed that in addition to high temperatures in May, high temperatures in June and July also lead Scots pine to produce narrow rings in Burabai Region. This result showed that Burabai Region has dry and continental conditions for tree-ring growth of Scots pine.

Precipitation is also a very important factor affecting tree-ring widths in the Burabai Region. In general, total precipitation from the October of the previous year to the July of current year has a positive influence on tree-ring width. This positive effect is mostly significant in November of the previous year and during the period of April-July trees need precipitation almost whole year, because the area receives very little precipitation during the year (Figs. 3, 6). Our results are consistent with previous dendroclimatological research carried out near the study area. For example, Shah et al. (2015) stated that monthly precipitation from August of the previous year to September of the current year is the most important restricted factor on tree-ring growth of Pinus sylvestris in central Siberia and has a significant positive correlation. Babushkina et al. (2015) also stated that precipitation from September of previous year to July of current year (except August) has a positive influence on tree-ring widths of Scots pine in south-central Siberia. Mapitov and Zhumadina (2016) also showed significantly positive influence of precipitation on tree-ring width in the northeast of Kazakhstan.

Because the area has a short but a very dry summer, trees are negatively affected from high temperatures in summer. In this region, annual precipitation is rather low $(\sim 300 \mathrm{~mm})$. Moreover, about half of 


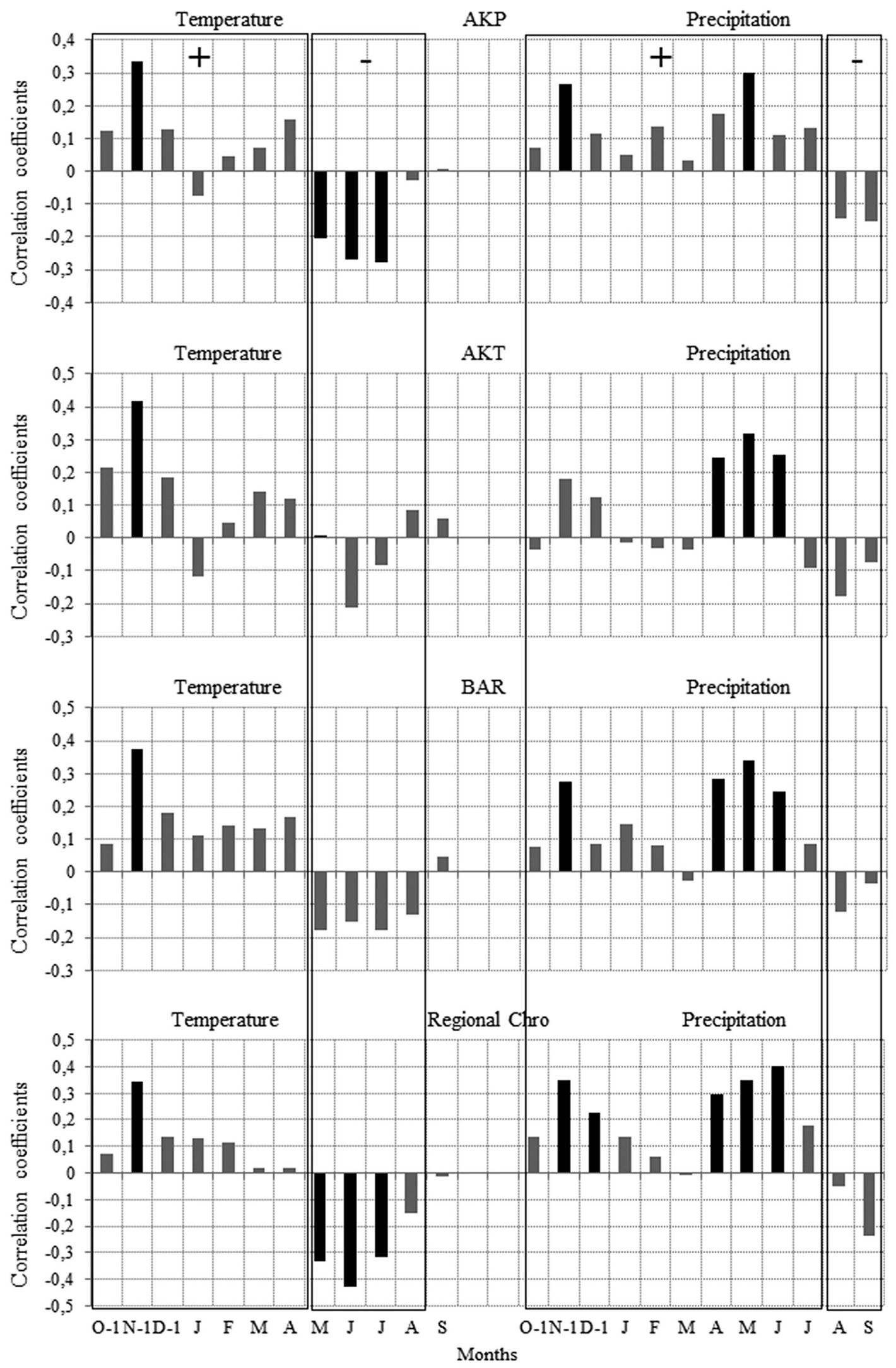

Fig. 6. Correlation coefficients between tree-ring site and regional chronologies with mean monthly temperatures and total monthly precipitation from October of the previous year to September of current year. Bold columns show the significant months at least at the level of $95 \%$ 

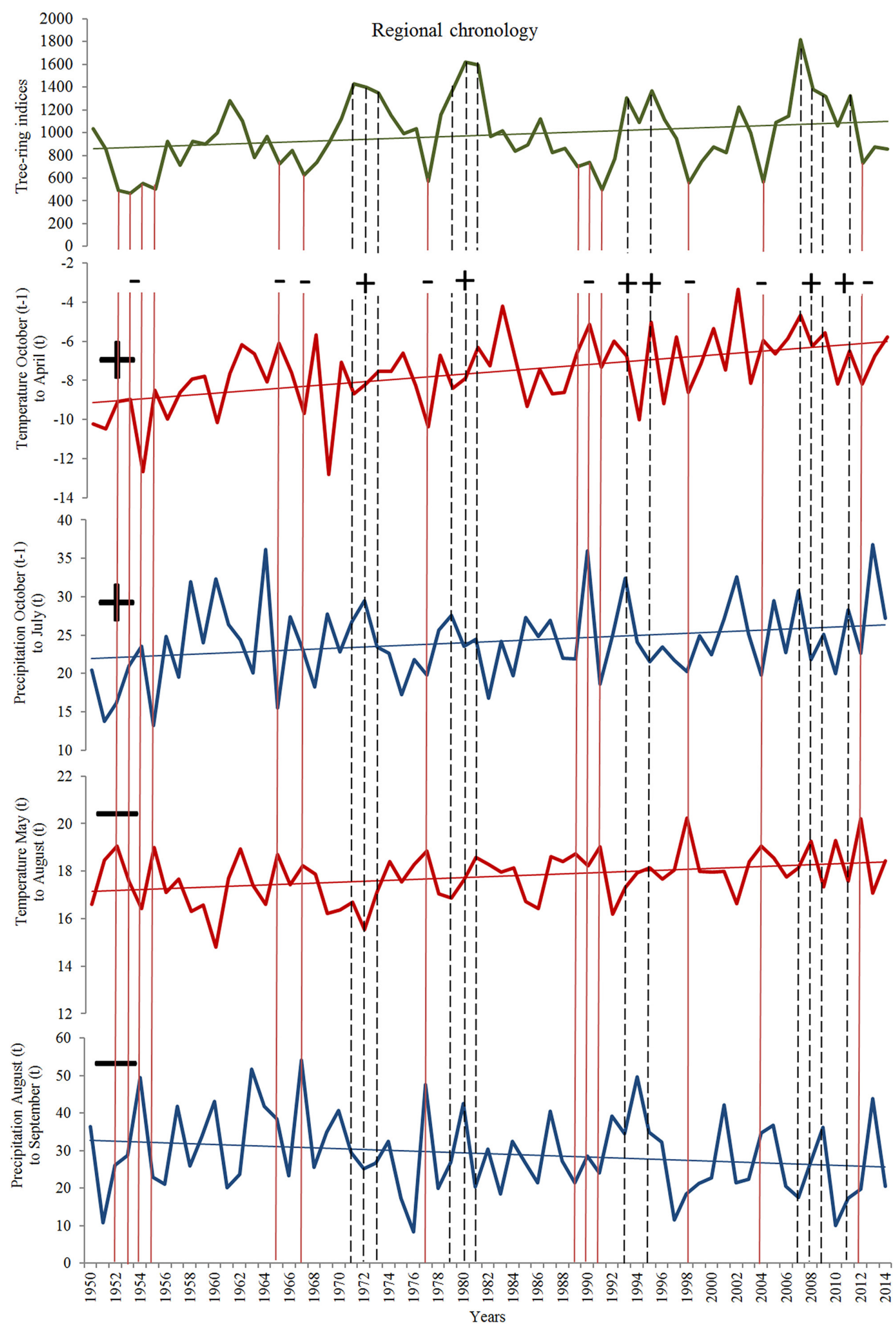

Fig. 7. Regional chronology and average temperature from October (t-1) to April, average temperature from May to August, total precipitation from October ( $\mathrm{t}-1)$ to July, and total precipitation from August and September. Vertical dotted lines show extreme positive years, and solid lines show extreme negative years given in Table 5 
annual precipitation $(154.3 \mathrm{~mm})$ falls in the growing season, during May to August (Fig. 3). Average temperature is $17.7^{\circ} \mathrm{C}$ for these months. Together with a low precipitation for radial growth, high temperatures cause water losses by evapotranspiration during those hot summer days. Because this time interval is the growing season, trees need more rain and lower average temperatures for these summer months (May to August) (Fig. 6).

For a better understanding of the collective effect of precipitation and temperature on tree-ring width in a given year, the most important climatic factors mentioned above were compared visually with the regional chronology (Figs. 6, 7). Here, four groups of climatic factors were depicted: (1) mean temperatures from previous October ( $\mathrm{t}-1)$ to current April (having positive impact on radial growth), (2) mean temperatures from May to August (leading to a negative response), (3) total precipitation from previous October (t-1) to current July (having a positive impact) and (4) total precipitation from August to
Table 5. Extreme negative and positive years from 1866 to 2014

\begin{tabular}{|c|c|c|}
\hline & Extreme negative years & Extreme positive years \\
\hline \multirow{5}{*}{ 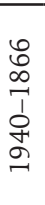 } & $1869-1870$ & 1886 \\
\hline & 1872 & 1889 \\
\hline & 1900 & 1907 \\
\hline & 1916 & 1922 \\
\hline & 1931 & \\
\hline \multirow{8}{*}{ 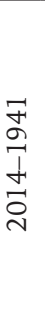 } & $1952-1955$ & 1944-1947 \\
\hline & 1965 & 1971-1973 \\
\hline & 1967 & 1979-1981 \\
\hline & 1977 & 1993 \\
\hline & 1989-1991 & 1995 \\
\hline & 1998 & 2007-2009 \\
\hline & 2004 & 2011 \\
\hline & 2012 & \\
\hline
\end{tabular}

September (with negative impact). For comparison, we indicated the extreme negative (dry) and positive (humid) years (Table 5) with vertical lines (Fig. 7). For instance, in the year 2012 Scots pine trees
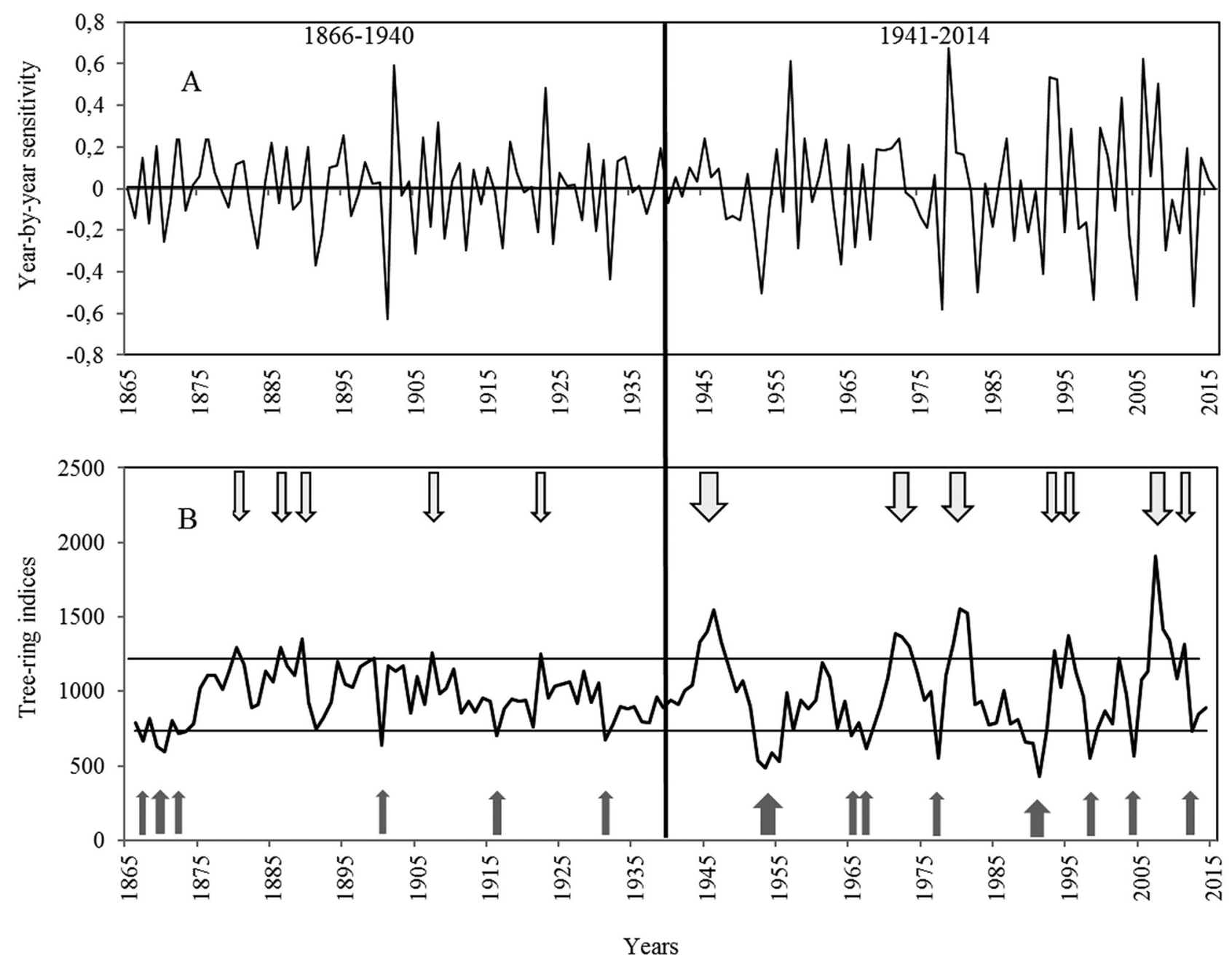

Fig. 8. A) Year-by-year sensitivity of mean chronology. The sensitivity is getting increase after 1950s; B) Extremity of the mean tree-ring chronology. The vertical line shows the arbitrary treshold in the year of 1940 . The extremity is lower before 1940s, and getting increasing after this time (Wider arrows show long extreme periods) 
Table 6. Correlation coefficients among the site chronologies and the regional chronology for the periods 1866-1940 and 1941-2014. Correlations are slightly higher in second period

\begin{tabular}{lcccccccc}
\hline & \multicolumn{9}{c}{$1866-1940$} & \multicolumn{2}{c}{$1941-2014$} \\
\cline { 2 - 8 } & AKP & AKT & BAR & Regional chro. & AKP & AKT & BAR & Regional chro. \\
\hline AKP & 1 & & & & 1 & & & \\
AKT & 0.68 & 1 & & & 0.71 & 1 & \\
BAR & 0.78 & 0.71 & 1 & & 0.80 & 0.76 & 1 & \\
Regional chro. & 0.87 & 0.86 & 0.95 & 1 & 0.91 & 0.85 & 0.96 & 1 \\
\hline
\end{tabular}

All values are statistically significant $(\mathrm{p} \leq 0.001)$.

produced narrow rings in the region. For this year, both temperature (October (t-1) to April) and precipitation (October ( $\mathrm{t}-1)$ to July) values, which had positive influence on radial growth, were lower than the average, while summer precipitation, which had a negative influence, is higher than the average. For 2007 , tree-ring width was extremely wide. This was a year of high temperatures and precipitation. This has a positive influence, increasing tree-ring width together with low summer temperatures and low late summer precipitation (Fig. 7). In most of the years, a wide or a narrow ring formation can be explained as the collective effect of both temperature and precipitation in the same year. In 1977 and 2004, similar collective effects of temperature and precipitation cause narrow ring formation in the region. Moreover, some of the trees have missing rings in these years (Table 2).

We observed distinct trends in the regional chronology, which could be attributed to climate change:

Tree-ring widths are increasing slightly (Fig. 7). Instrumental records show that total precipitation from October of the previous year to July of the current year, and average temperature from October of
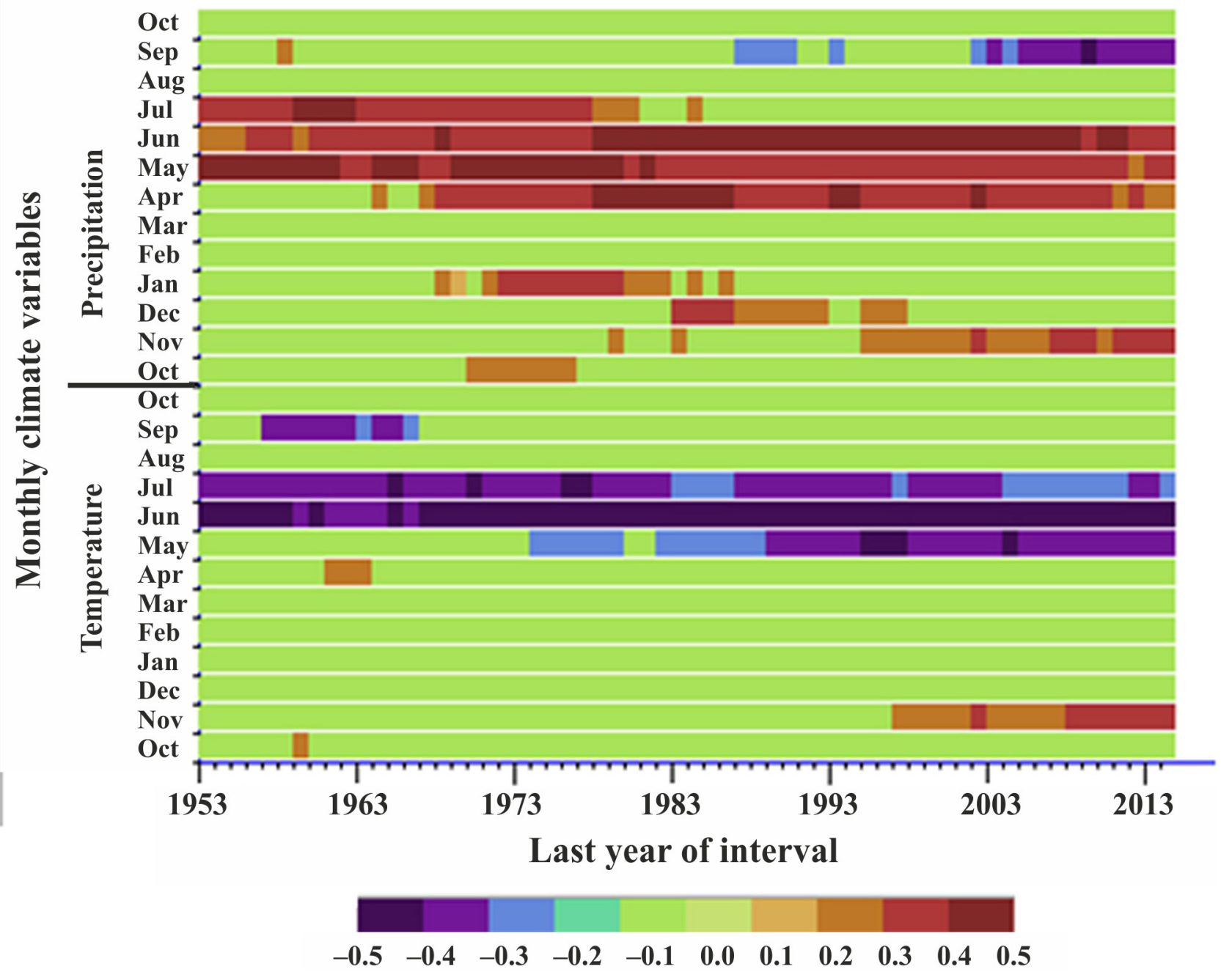

Fig. 9. The correlations between the regional chronology and monthly temperature and precipitation calculated using the method moving interval method 
the previous year to April of the current year are increasing (Fig. 7). Increase in tree-ring widths starting in the 1940's is parallel with the trend in these climate parameters. Results of correlation coefficients between tree-ring widths with this precipitation and temperature showed that these events have positive influence on tree-ring width. On the contrary, summer temperatures, resulting in dry conditions and producing narrow rings, are also increasing. Tree-ring chronologies showed a similar increasing trend in recent decades in the Northern Hemisphere (Cook et al., 2015, George \& Ault, 2014, D’Arrigo et al., 2000). Meteorological records for the period of 1950-2015 showed that total precipitation from previous October to current July, which has positive influence on radial growth, is increasing. Conversely, August-September total precipitation, which has negative influence on radial growth, is decreasing. In this case, both of these changes may also have a collective positive influence on tree-ring width and contribute to increase in sensitivity.

Sensitivity of tree rings is increasing. 1940 can be accepted as an arbitrary starting year of increasing sensitivity. Sensitivities were calculated for each year in a window centered at this year (1866-1940 and 1940-2014). Mean sensitivity for the standardized series (1866-2014) is 0.23 ; 0.20 for $1866-1940$ period and 0.26 for 1940-2014 (Fig. 8A). The correlation coefficients among all site chronologies and regional chronology are slightly higher in 1941-2014 than in 1866-1940 (Table 6), as well. This can be interpreted as trees responding to drivers (precipitation and temperature) more efficiently after 1940s. Moving interval method results showed some changes from 1950s into the last decades. This change can be clearly seen as an increasing trend in April-June precipitations and May-June temperatures from 1950s till 2010s (Fig. 9).

Year-by-year sensitivity of October to July total precipitation, which effects radial growth positively, agree with tree-ring sensitivity. An opposite relation between the sensitivity of temperature and tree rings is clearly observed, especially in extreme years (e.g.1977, 1991, 1999 and 2003), because the effect of temperature on tree-ring width is significantly negative (Fig. 10).

Frequency of extreme years is increasing (Fig. $8 \mathrm{~B}$; Table 5). The number of negative extreme years from 1866 to 1940 is 6 versus 13 during the period of 1940-2014. When duration of extreme negative years is generally 1 or 2 years long before 1940s, it ranges 1 to 4 -years after that. Its duration is 4 years long between the years 1952 and 1955, and 3 years between 1989 and 1991. It is clear that both the frequency and duration of the extreme negative years are increasing. The missing rings given in Table 2 are recognized in these extreme negative years (Fig. 8B). These years are generally more sensitive than others are and cause increased sensitivity in recent decades. The numbers of positive extreme years before 1940 is only four and all these events are of one year duration. However, after 1940 the number of extreme positive events increased abruptly (up to 16). It looks obvious that extreme positive events are increasing in Burabai Region. Their durations are generally one or two-year period (Fig. 8B). The longest positive extreme period was 4 years long, covered 19441947. This finding also confirmed that the reasons of increasing trend in tree-ring widths are increasing with both temperature and precipitation in Burabai

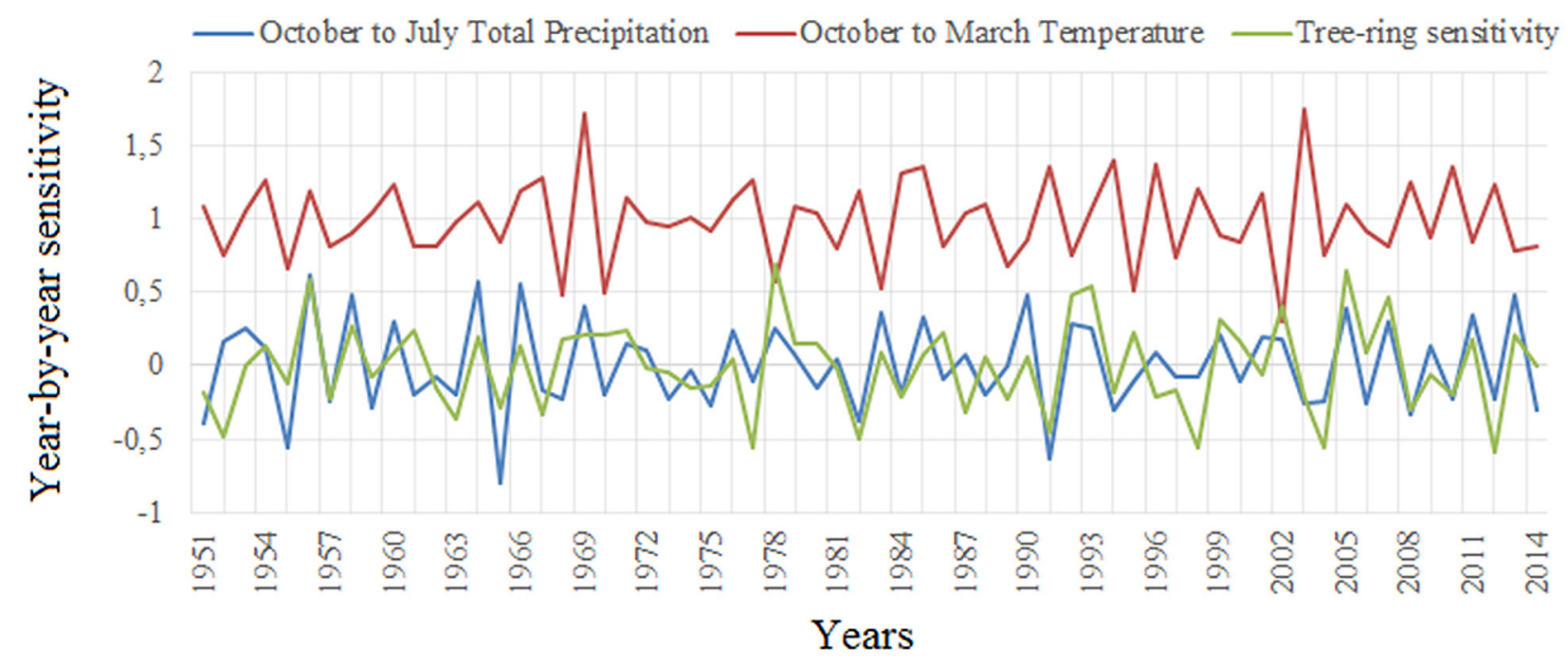

Fig. 10. Year-by-year sensitivity of October to July total precipitation, October to March temperature and the regional chronology. Precipitation effects radial growth positively, agree with tree-ring sensitivity, whereas an opposite relation between the sensitivity of temperature and tree rings is clearly observed, especially in extreme years (e.g.1977, 1991, 1999 and 2003) 
Region. As also indicated in IPCC Report (2015), extreme events are getting more frequent in recent decades in the region. Increasing sensitivities and an increasing trend in extreme years also supports this conclusion.

\section{Conclusion}

Burabai Region has large Pinus sylvestris forest areas located on both bottomlands and mountain areas. Collected samples produced the longest tree-ring chronology covering the years of 1699-2014. Chronology statistics revealed very high and significant correlations. This implies that trees respond strongly to similar events in Burabai Region. In the Burabai Region, under continental climate conditions, there is a strong relationship between tree-ring widths with both temperature and precipitation. Trees positively respond to warm winter temperature and high amount of total precipitation except August-September. Although it is difficult to explain the negative effect of August-September precipitation, high precipitation of these months may cause a shortened growing season. Dendrometer measurements in these regions may help to resolve this issue. Opposite effects of summer precipitation and temperature on tree-ring widths are clearly shown. When temperature increases in summer, and precipitation decreases, tree-ring widths also decrease. On the contrary, if temperature decreases in summer and precipitation increases then the tree-ring widths increase. Reverse effects of precipitation and temperature in the same months causes the formation of narrow or wide rings.

In Burabai Region climate is changing. Both temperature and precipitation show an increasing trend from 1940s on. We also can conclude that the number of extreme events tends to increase in Burabai Region. The number and duration of positive extreme years are on the rise after 1940. The results may suggest that Pinus sylvestris in Burabai region will grow faster in the near future. However this positive tendency seems to be disrupted at much drier sites of Burabai (e.g. Akylbai Mountain top). This is because drought causes very narrow ring formation or missing ring for the trees in mountainous sites. High number of missing rings in the trees indicated an increasing risk for the trees. Information on the relationships between tree-ring width and climate, and ring growth pattern of Pinus sylvestris may be applied to modify forest management practices in this recently changing and challenging environment.

\section{Acknowledgement}

This study was performed during the studies of Arailym Kopabaeva's doctorate thesis supported by
S.Seyfullin Agroteknik University. We thank Director of Forest Service in Burabai Region for permission and the foresters for their helps in the field. We also thank Jeffrey Wall for editing the English language of the paper.

\section{References}

Agafonov LI \& Kukarskikh VV (2008) Climate changes in the past century and radial increment of pine in the Southern Urals steppe. Russian Journal of Ecology 39: 160-167..

Akkemik U, D’Arrigo R, Cherubini P, Köse N \& Jacoby GC (2008) Tree-ring reconstructions of precipitation and streamflow for north-western Turkey. International Journal of Climatology 28: 173-183.

Akkemik Ü, Dağdeviren N \& Aras A (2005) A preliminary reconstruction (A.D. 1635-2000) of spring precipitation using oak tree rings in the western Black Sea region of Turkey. International Journal of Biometeorology 49: 297-302.

Akkemik Ü \& Aras A (2005) Reconstruction (16891994 AD) of April-August precipitation in the southern part of central Turkey. International Journal of Climatology 25: 537-548.

Babushkina EA, Vaganov EA, Belokopytova LV, Shishov VV \& Grachev AM (2015) Competitive strength effect in the climate response of Scots pine radial growth in South-central Siberia forest-steppe. Tree-Ring Research 71: 106-117.

Biondi F \& Waikul K (2004) DENDROCLIM2002: a $\mathrm{C}++$ program for statistical calibration of climate signals in tree-ring chronologies. Computers \& Geosciences 30: 303-311.

Bunn AG, Jansma E, Korpela M, Westfall RD \& Baldwin J (2013) Using simulations and data to evaluate mean sensitivity $(\zeta)$ as a useful statistic in dendrochronology. Dendrochronologia 31: 250-254.

Büntgen U, Tegel W, Nicolussi K, McCormick M, Frank D, Trouet V, Kaplan JO, Herzig F, Heussner KU, Wanner H, Luterbacher J \& Esper J (2011) 2500 years of European climate variability and human susceptibility. Science 331: 578-582.

Büntgen U, Myglan VS, Ljungqvist FC, McCormick M, Di Cosmo N, Sigl M, Jungclaus J, Wagner S, Krusic PJ, Esper J, Kaplan JO, de Vaan MAC, Luterbacher J, Wacker L, Tegel W \& Kirdyanov AV (2016) Cooling and societal change during the Late Antique Little Ice Age from 536 to around 660 AD. Nature Geosciences 9: 231-236.

Chen F, Yuan YJ, Wei WS, Yu SL, Li Y, Zhang RB, Zhang TW \& Shang HM (2010) Chronology development and climate response analysis of Schrenk spruce (Picea Schrenkiana) tree-ring pa- 
rameters in the Urumqi river basin, China. Geochronometria 36: 17-22.

Chen J, Wang LL, Zhu HF \& Wu P (2009) Reconstructing mean maximum temperature of growing season from the maximum density of the Schrenk Spruce in Yili, Xinjiang, China. Chinese Science Bulletin 54: 2300-2308.

Cook E (1985) A time series analysis approach to tree-ring standardization. Unpublished $\mathrm{PhD}$ dissertation, University of Arizona, Tucson.

Cook E, Briffa K, Shiyatov S \& Mazepa V (1990) Tree-ring standardization and growth-trend estimation: Methods of Dendrochronology (ed. by E Cook \& K Briffa) Kluwer, Dordrecht, pp. 104-123.

Cook ER, Seager R, Kushnir Y, Briffa KR, Büntgen U, Frank D, Krusic PJ, Tegel W, van der Schrier G, Andreu-Hayles L, Baillie M, Baittinger M, Bleicher N, Bonde N, Brown D, Carrer M, Cooper R, Čufar K, Dittmar C, Esper J, Griggs C, Gunnarson B, Günther B, Gutierrez E, Haneca K, Helama S, Herzig F, Heussner KU, Hofmann J, Janda P, Kontic R, Köse N, Kyncl T, Levanič T, Linderholm H, Manning S, Melvin TM, Miles D, Neuwirth B, Nicolussi K, Nola P, Panayotov M, Popa I, Rothe A, Seftigen K, Seim A, Svarva H, Svoboda M, Thun T, Timonen M, Touchan R, Trotsiuk V, Trouet V, Walder F, Ważny T, Wilson R \& Zang C (2015) Old World megadroughts and pluvials during the Common Era. Science Advances 1: e1500561.

Corona C, Guiot J, Edouard JL, Chalié F, Büntgen U, Nola P \& Urbinati C (2010) Millennium-long summer temperature variations in the European Alps as reconstructed from tree rings. Climate of the Past 6: 379-400.

D’Arrigo R, Jacoby G, Pederson N, Frank D, Buckley B, Nachin B, Mijiddorj R \& Dugarjav C (2000) Mongolian tree-rings, temperature sensitivity and reconstructions of Northern Hemisphere temperature. The Holocene 10: 669-672.

Dyakonov KN \& Retejum AJ (2015) Dendroindication of the planets-induced climate anomalies: Eurodendro 2015. Climate and human history in the mediterranean basin: book of abstracts (ed. by Ü Akkemik) Antalya, Turkey, pp: 44-47.

Eckstein D \& Bauch J (1969) Beitrag zur rationalisierung eines dendrochronologischen verfahrens und zur analyse seiner aussagesicherheit. Forstwissenschaftliches Centralblatt 88: 230-250.

Esper J, Schweingruber FH \& Winiger M (2002) 1300 years of climatic history for Western Central Asia inferred from tree-rings. The Holocene 12: 267-277.

Esper J, Frank D, Büntgen U, Verstege A, Luterbacher J \& Xoplaki E (2007) Long-term drought severity variations in Morocco. Geophysical Research Letters 34: L17702. doi:10.1029/2007GL030844.
Fritts HC (1976) Tree rings and climate. Kluwer Academic Publishers, New York.

George SS \& Ault TR (2014) The imprint of climate within Northern Hemisphere trees. Quaternary Science Reviews 89: 1-4.

Gogou A, Triantaphyllou M, Xoplaki E, Izdebski A, Parinos C, Dimiza M, Bouloubassi I, Luterbacher J, Kouli K, Martrat B, Toreti A, Fleitmann, Rousakis G, Kaberi H, Athanasiou M \& Lykousis V (2016) Climate variability and socio-environmental changes in the northern Aegean (NE Mediterranean) during the last 1500 years. Quaternary Science Reviews 136: 209-228.

Holmes RL (1983) Computer-assisted quality control in tree-ring data and measurements. Treering Bulletin 43: 69-78.

Holmgren K, Gogou A, Izdebski A, Luterbacher J, Sicre MA \& Xoplaki E (2016) Mediterranean Holocene climate, environment and human societies. Quaternary Science Reviews 136: 1-4.

Hughes MK (2002) Dendrochronology in climatology-the state of the art. Dendrchronologia 20: 95-116.

IPCC (2015) Climate Change 2014 Synthesis Report. A Report of the Intergovernmental Panel on Climate Change.

Kausrud KL, Begon M, Ben Ari T, Viljugrein H, Esper J, Büntgen U, Leirs $H$, Junge C, Yang B, Yang M, Xu L \& Stenseth NC (2010) Modeling the epidemiological history of plague in Central Asia: paleoclimatic forcing on a disease system over the past millennium. BMC Biology 8: 112. doi:10.1186/1741-7007-8-112.

Köse N, Akkemik U, Dalfes HN \& Ozeren MS (2011) Tree-ring reconstructions of May-June precipitation for western Anatolia. Quaternary Research 75: 438-450.

Köse N, Akkemik Ü, Güner HT, Dalfes HN, Grissino-Mayer H, Özeren S \& Kindap T (2013) AN improved reconstruction of May-June precipitation using tree-ring data from western Turkey and its links to volcanic eruptions. International Journal of Biometeorology 57: 691-701.

Luterbacher J, Werner JP, Smerdon JE, Fernández-Donado L, González-Rouco FJ, Barriopedro D, Ljungqvist FC, Büntgen U , Zorita E, Wagner S, Esper J, McCarroll D, Toreti A, Frank D, Jungclaus $\mathrm{JH}$, Barriendos $\mathrm{M}$, Bertolin $\mathrm{C}$, Bothe $\mathrm{O}$, Brázdil R, Camuffo D, Dobrovolný P, Gagen M, GarcíaBustamante E, Ge Q, Gómez-Navarro JJ, Guiot J, Hao Z, Hegerl GC, Holmgren K, Klimenko VV, Martín-Chivelet J, Pfister C, Roberts N, Schindler A, Schurer A, Solomina O, von Gunten L, Wahl E, Wanner H, Wetter O, Xoplaki E, Yuan N, Zanchettin D, Zhang H \& Zerefos C (2016) European summer temperatures since Roman times. Environmental Research Letters 11: 024001. 
Mapitov N \& Zhumadina S (2016) Tree-ring analysis of radial increment of Pinus sylvestris L. in Shalday pine forest in the northeast of Kazakhstan. Research Journal of Pharmaceutical, Biological and Chemical Sciences 7: 180-187.

Petrova E \& Sultangazina G (2015) The current state of the tree-shrub flora in the National Park Burabai. UDK 528.35/99 (574.23), Kostanay State University, Kostanay, Kazakhstan.

Pugachev PG (1986) Cyclicism and forecast of radial increment of Pinus sylvestris L. in Turgai boreal forests. Dendrochronology and dendroclimatology. Nauka, Novosibirsk pp. 184-186.

Rigling A, Waldner PO, Forster T, Bräker OU \& Pouttu A (2001) Ecological interpretation of tree-ring width and intraannual density fluctuations in $\mathrm{Pi}$ nus sylvestris on dry sites in the central Alps and Siberia. Canadian Journal of Forest Research 31: 18-31.

Tegel W, Vanmoerkerke J \& Büntgen U (2010) Updating historical tree-ring records for climate reconstruction. Quaternary Science Reviews 29: 1957-1959.

Shah SK, Touchan R, Babushkina E, Shishov VV, Meko DM, Abramenko OV, Belokopytova LV, Hordo M, Jevšenak J, Kędziora W, Kostyakova TV, Moskwa A, Oleksiak Z, Omurova G, Ovchinnikov S, Sadeghpour M, Saikia A, Zsewastynowicz Ł, Sidenko T, Strantsov A, Tamkevičiūtè M, Tomusiak R \& Tychkov I (2015) August to July precipitation from tree rings in the forest-steppe zone of central Siberia (Russia). Tree-Ring Research 71: 37-44.

Touchan R, Akkemik U, Hughes MK \& Erkan N (2007) May-June precipitation reconstruction of southwestern Anatolia, Turkey during the last 900 years from tree-rings. Quaternary Research 68: 196-202.

Touchan R, Xoplaki E, Funhouser G, Luterbacher J, Hughes MK, Erkan N, Akkemik U \& Stephan J
(2005) Reconstructions of spring/summer precipitation for the Eastern Mediterranean from tree-ring widths and its connection to large-scale atmospheric circulation. Climate Dynamics 25: 75-98.

Wilson R, Anchukaitis K, Briffa KR, Büntgen U, Cook E, D’Arrigo R, Davi N, Esper J, Frank D, Gunnarson B, Hegerl G, Helama S, Klesse S, Krusic PJ, Linderholm HW, Myglan V, Osborn TJ, Rydval M, Schneider L, Schurer A, Wiles G, Zhang P \& Zorita E (2016) Last millennium northern hemisphere summer temperatures from tree rings: Part I: The long term context. Quaternary Science Reviews 134: 1-18. doi: 10.1016/j.quascirev.2015.12.005.

Wigley TML, Briffa KR \& Jones PD (1984) On the average value of correlated time series, with applications in dendroclimatology and hydrometeorology. Journal of Applied Meteorology 23: 201-213.

Xoplaki E, Fleitmann D, Izdebski A, Luterbacher J, Wagner S, Haldon JF, Zorita E, Telelis I, Toreti A \& Izdebski A (2016) The Medieval Climate Anomaly and Byzantium; a review of evidence on climatic fluctuations, economic performance and societal change. Quaternary Science Reviews 136: 229-252.

Yuan YJ, Jin LY, Shao XM, He Q, Li ZZ \& Li JF (2003) Variations of the spring precipitation day numbers reconstructed from tree rings in the Urumqi River drainage, Tianshan Mts. Over the last 370 years. Chinese Science Bulletin 48: 1507-1510.

Yuan YJ, Li JF \& Zhang JB (2001) 348-year precipitation reconstruction from tree-rings for the North Slope of the middle Tianshan Mountains. Journal of Meteorogical Research 15: 95-104.

Yuan YJ \& Li JF (1999) Reconstruction and analysis of 450 years winter temperature series in the Urumqi River source of Tianshan Mountains. Journal of Glaciology and Geocryology 21: 64-70. 